\title{
TEORI HASIL BELAJAR PADA SISWA SDIT CENDIKIA
}

\author{
Hilwatunnisa NurLayali \& Sarah Sohiah \\ Universitas Muhammadiyah Tangerang \\ hilwatunnisa@umt.ac.id,sarah.sohiah@umt.ac.id
}

\begin{abstract}
Student learning outcomes are influenced by many factors, including student interst and learning motivation. Learning outcomes are a number of experiences gained by students who encompass the cognivite realm is the ability of students to work on the problems given. This article discusses the influence of students interest and motivation on learning outcomes in lesson sd in SDIT GLOBAL CENDIKIA. To improve learning outcomes it is necessary to develop a learning method that can improve student activities and learning outcomes through classroom action research. This research method uses data collection in the from of observation. From the analysis of student learning outcomes obtained in the cognitive domain that value of student evaluation questions given by the teacher when the learning process takes place. The results of this study can be used SDIT GLOBAL CENDIKIA to find out the learning styles of student learning outcomes and can be used for considerration of schools and parents of students to improve attention to students, especially those in grades $V$ AND VI.
\end{abstract}

Keywords: interest in learning, motivation learning, outcomes learning, styles of learning

\begin{abstract}
Abstrak : Hasil belajar siswa dipengaruhi oleh banyak faktor, diantaranya adalah minat dan motivasi belajar siswa. Hasil belajar adalah sejumlah pengalaman yang diperoleh siswa yang mencakup ranah kognitif adalah kemampuan siswa dalam mengerjakan soal yang diberikan. Artikel ini membahas hasil penelitian tentang pengaruh minat dan motivasi belajar siswa terhadap hasil belajar pada pelajaran sd di SDIT CENDIKIA. Untuk meningkatkan hasil belajar tersebut perlu dikembangkan suatu metode belajar yang dapat meningkatkan aktivitas dan hasil belajar siswa melalui penelitian tindakan kelas. Metode penelitian ini menggunakan pengumpulan data berupa observasi. Dari analisis hasil belajar siswa diperoleh pada ranah kognitif yaitu pada nilai evaluasi siswa pada saat mengerjakan soal evaluasi yang diberikan oleh guru saat proses kegiatan belajar mengajar berlangsung. Hasil penelitian ini dapat digunakan SDIT CENDIKIA untuk mengetahui gaya belajar terhadap hasil belajar siswa serta dapat digunakan untuk pertimbangan sekolah serta orang tua siswa untuk memperbaiki perhatian kepada siswa terutama yang berada di Kelas V dan VI.
\end{abstract}

Kata Kunci : Minat Belajar, Motivasi Belajar, Hasil Belajar, Gaya Belajar

\section{PENDAHULUAN}

Proses belajar terjadi karena adanya suatu tujuan yang ingin dicapai. Tujuan yang dimaksud adalah berupa hasil belajar. Hasil belajar harus menunjukkan suatu perubahan tingkah laku yang bersifat menetap, fungsional, positif dan disadari. Perwujudan hasil belajar akan selalu berkaitan dengan kegiatan evaluasi. Untuk itu 
diperlukan teknik dan prosedur evaluasi belajar yang dapat menilai secara efektif proses dan hasil belajar.

Belajar adalah key term (istilah kunci) yang paling vital dalam setiap pendidikan, sehingga tanpa belajar sesungguhnya tidak pernah ada pendidikan. Dalam pengertian yang luas, pendidikan diartikan sebagai sebuah proses dengan metode-metode tertentu sehingga orang memperoleh pengetahuan, pemahaman, dan cara bertingkah laku yang sesuai dengan kebutuhan. (Muhibbin Syah, 2010: 10)

Sebagai suatu proses, belajar hampir selalu mendapat tempat yang luas dalam berbagai disiplin ilmu yang berkaitan dengan upaya pendidikan. Perubahan dan kemampuan untuk berubah merupakan batasan dan makna yang terkandung dalam belajar. Selain itu, dengan kemampuan berubah melalui belajar itu, manusia secara bebas dapat mengeksplorasi, memilih, dan menetapkan keputusan-keputusan penting untuk kehidupannya.( H.M. Surya 2016:8.6)

Setiap siswa pada prinsipnya tentu berhak memperoleh peluang untuk mencapai kinerja akademik (academic performance) yang memuaskan. Namun dari kenyataan sehari-hari tampak jelas bahwa siswa itu memiliki perbedaan dalam hal kemampuan intelektual, kemampuan fisik, latar belakang keluarga, kebiasaan dan pendekatan belajar yang terkadang sangat memcolok antara siswa dengan siswa lainnya.

Hal ini timbul sebuah masalah atau kesulitan belajar yang dapat dialami oleh setiap siswa dan menjadi tanggung jawab pendidik dikarenakan kinerja akademiknya terhambat oleh beberapa faktor. Pentingnya penyelenggaraan pendidikan agar terlebih dahulu melakukan identifikasi terhadap hal-hal yang menghambat dalam proses dan hasil belajarnya.

\section{METODE PENELITIAN}

\section{Jenis penelitian}

Dalam penelitian ini menggunakan data deskripsi yang diperoleh dalam pengumpulan data yang melalui observasi, wawancara, dokumentasi. 


\section{Waktu dan Tempat Penelitian}

Penelitian ini dilaksanakan di SDIT GLOBAL CENDIKIA yang beralamat di KP. Doyong RT 05/13 Kel. Gembor Kec. Periuk Kota Tangerang. pada tahun ajaran 2019/2020. Lokasi tersebut dipilih berdasarkan pertimbangan penelitian karena pengembangan bahan ajar di sekolah cukup berkembang dan mengikuti era globalisasi walaupun siswa dan siswinya kurang memadai.

\section{Target/Subjek Penelitian}

Yang menjadi Subjek dalam penelitian ini adalah siswa kelas V dan VI di SDIT GLOBAL CENDIKIA.

\section{Prosedur}

Penelitian ini menggunakan tipe penelitian kualitatif. Data diperoleh melalui dari proses obervasi, wawancara, dokumentasi, dan catatan lapangan. Dari pengumpulan informasi melalui observasi, wawancara, dokumentasi dan catatan lapangan, kemudian penyimpulan pengatasan dan penyimpulan hasil.

\section{Data, Intrumen, dan Teknik Pengumpulan Data}

Teknik pengumpulan data dalam penelitian menggunakan teknik observasi, wawancara, dokumentasi, dan catatan lapangan. Selain itu peneliti juga menggunakan kuesioner yang dilakukan dengan cara memberi seperangkat pertanyaan atau pernyataan SDIT GLOBAL CENDIKIA.

\section{Teknik Analisis Data}

Teknik data dilakukan sesuai dengan prosedur ilmiah penelitian kualitatif. Pada penelitian ini menggunakan metode analisis dari Milles dan Huberman. Dalam teknik analisis ini terdapat tiga tahap yaitu reduksi data, penyajian data, dan verifikasi data. Reduksi data bertujuan untuk menyederhanakan data yang abstrak menjadi sebuah rangkuman yang jelas dan terperinci. Data tersebut dihasilkan dari proses obervasi, wawancara, dakumentasi, dan catatan lapangan. Proses selanjutnya adalah penyajian data. Setelah direduksi kemudian data disajikan kedalam bentuk yang lebih sederhana dalam bentuk paparan naratif dan hasil penelitian tentang pengembangan bahan ajar. 
Kemudian langkah terakhir adalah verifikasi data. Data yang telah diproses kemudian ditarik kesimpulan.

\section{HASIL PENELITIAN DAN PEMBAHASAN}

Berdasarkan fakta lapangan di SDIT Global Cendikia pada saat itu guru mengajar kepada murid-muridnya mengenai bab Tata Surya. Metode pembelajaran yang digunakan di kelas 5 yang di dalamnya ada siswa dan siswi kelas 5. Guru menstimulasi murid-muridnya dengan mengajak murid-muridnya untuk bernyanyi bersama. Berikut metode pembelajaran yang digunakan.

- $\quad$ Pada saat awal pembelajaran guru menggunakan metode ceramah, yang mana guru menjelaskan terlebih dahulu materi pelajaran yang akan dibahas secara lisan.

- $\quad$ Lalu selanjutnya guru menggunakan metode tanya jawab. Guru menunjuk murid untuk menjawab pertanyaan. Dengan mengajukan pertanyaan yang terarah, siswa akan tertarik dalam mengembangkan daya pikir. Kemampuan berpikir siswa dan keruntutan dalam mengemukakan pokok - pokok pikirannya dapat terdeteksi ketika menjawab pertanyaan.

- $\quad$ Setelah itu, guru menggunakan metode penugasan yang berartiguru memberi tugas tertentu agar siswa melakukan kegiatan belajar.Metode ini dapat mengembangkan kemandirian siswa, meransang untuk belajar lebih banyak, membina disiplin dan tanggung jawab siswa, dan membina kebiasaan mencari dan mengolah sendiri informasi.

Berdasarkan pengamatan kami, di SDIT Global Cendikia untuk kelas 5 perspektif motivasi dalam pembelajaran cenderung lebih condong pada motivasi perspektif sosial dan perspektif kognitf karena siswa SD pada kelas 5 cenderung lebih aktif dalam pembelajaran yang diajarkan guru mereka dalam kelas. Terdapat jalinan hubungan positif terhadap guru yang mengajar dikelas dengan siswa- siswi tersebut serta mereka termotivasi secara kompetensi yaitu dapat menciptakan suasana yang efektif antara guru dan siswanya melalui nyanyian yang edukatif berkaitan dengan pembelajaran. Serta siswa-siswi tersebut tidak merasa terbebani dalam mata pelajaran yang diajarkan guru mereka. Mereka belajar dengan susana yang menyenangkan. 
Kami mengajukan beberapa pertanyaan untuk siswa dan siswi yang berprestasi. Bagaimana cara belajar mereka sehingga bisa menjadi juara kelas.

1. Ahmad maulana

Ahmad maulana mendapat juara 1 pada saat kenaikan kelas. Ahmad belajar dengan sangat giat dengan dibantu ibu nya di rumah. Cara belajar nya ahmad lebih baik belajar dengan menyendiri karena dengan itu pelajarannya dapat dimengerti. Walaupun saat di sekolah ahmad lebih pendiam tetapi ia siswa yang berprestasi dan menbuat bangga orangtuanya.

2. Putri mauludina

Putri mauludina mendapat juara 2 pada saat kenaikan kelas. Putri mengikuti eskul marawis di sekolahnya tetapi ia tidak melupakan tugasnya sebagai seorang pelajar. Sehabis pulang sekolah putri makan, tidur siang, dan malamnya ia belajar dan mengerjakan pr dengan dibantu oleh kakaknya.

3. Anna aulia putri

Anna aulia puri mendapat juara 3 pada saat kenaikan kelas. Anna murid yang cerdas, ceria dan ia cukup aktif di kelas. Pada saat kami mengajukan beberapa pertanyaan tentang mata pelajaran bahasa inggris anna yang paling banyak mengacungkan tangannya. Anna mengikuti les bahasa inggris sehabis selesai sekolah sebab itu ia cukup menguasai pelajaran tersebut.

Motivasi ekstrinsik adalah melakukan sesuatu untuk mendapatkan sesuatu yang lain ( cara untuk mencapai tujuan). Motivasi ekstrinsik sering dipengaruhi oleh insentif eksternal seperti hukuman dan imbalan. Berdasarkan hasil observasi kami di SDIT Global Cendikia kelas5 bahwa siswa mendapatkan motivasi eksternal disaat kami sedang melakukan sesi tanya jawab dengan memberi hadiah bagi siswa yang mengangkat tangan dan menjawab beberapa pertanyaan yang kami tanyakan. Sebagian besar siswa memiliki motivasi eksternal yang kuat untuk menjawab beberapa pertanyaan kami. Mereka dipengaruhi oleh kondisi dimana motivasi eksternal berupa pemberian hadiah cokelat dan juga melihat temannya yang lain antusias mengangkat tangan maka siswa atau murid juga termotivasi untuk menjawab pertanyaan dan mendapatkan hadiah. 


\section{KESIMPULAN}

Kegiatan observasi bagi mahasiswa calon guru sangatlah bermanfaat karena dapat memberikan pandangan awal bagi mahasiswa untuk mempersiapkan diri menjadi pendidik serta agar siap untuk terjun lansung kesekolah dasar.

Observasi yang dilakukan oleh Kelompok 12 Psikologi Pendidikan di SDIT Global Cendikia memberikan hasil yang cukup memuaskan kelompok. Dinamika manajemen kelas yang terjadi antara murid dan guru relevan dengan teori belajar dan motivasi yang ada. Metode pembelajaran yang diterapkan oleh para guru terhadap murid juga mendapat respon positif yang terlihat dari kemajuan berpikir para murid. Suasana kelas yang menyenangkan namun tetap kondusif juga memberi kesan "hangat", belajar tidak terlalu kaku tetapi tidak menghilangkan sisi formalnya.

Motivasi murid dalam belajar juga terlihat dari sikap antusias mereka dalam menjawab pertanyaan-pertanyaan yang diajukan guru secara lisan. Mereka tetap menjawab dengan percaya diri walaupun salah. Namun, masih ada beberapa murid yang enggan berpartisipasi karena mungkin masih ragu untuk menjawab (takut salah). Meskipun demikian, pemahaman murid tentang materi yang disampaikan guru tetap tersampaikan.

Para guru dan murid di SDIT Global Cendikia juga memiliki sikap ramah dan santun kepada tamu. Mereka menyambut anggota kelompok dengan baik dan ceria. Mereka juga langsung merasa akrab dan tidak canggung saat diajak bicara. Suasana kelas juga tetap belajar dengan kondusif meski ada tamu yang duduk di dalam kelas mereka.

\section{DAFTAR PUSTAKA}

Kustandi, d. (2013). Media Pembelajaran Manual dan Digital. Bogor: Ghalia Indonesia.

Santrock, J.W. (2015). Psikologi Pendidikan ed. 2. Jakarta: Kencana Prenada Media Grup.

Syah Muhibbin. (2016). Psikologi Pendidikan suatu Pendekatan Baru. Bandung : Remaja Rosda Karya.

Trianto. (2010). Pengantar Penelitian Pendidikan bagi Pengembangan Profesi Pendidikan dan Tenaga Kependidikan. Jakarta: Kencana Prenada Media Grup. 